\title{
Violence Attitude and Its Relation to Health-Related Habits in Medical Students' at Faculty of Medicine, Ain Shams University.
}

\author{
Aisha M. Aboul Fotouh, Ghada O. Wassif, Dalia G. Sos
}

Department of Community, Environmental and Occupational Medicine, Faculty of Medicine, Ain Shams University

\section{Abstract}

Background: Youth violence is a global public health problem. It includes a range of acts from bullying and physical fighting, to more severe sexual and physical assault to homicide. Worldwide an estimated 200000 homicides occur among youth 10-29 years of age each year, making it the fourth leading cause of death for people in this age group. Youth homicide rates vary dramatically between and within countries, being more common in developing countries than more developed ones. Researchers and prevention specialists are trying to identify the factors that increase young people attitude toward violence in order to plan for successful interventions and to design more effective prevention programs. Objectives: to measure medical students' attitude toward violence at Ain Shams university hospital and to find out the relations between medical students' scores on the attitudes toward violence, demographic variables, and health-related habits. Methods: A Descriptive cross-sectional study was carried out at Faculty of Medicine, Ain Shams University; 1257 Medical Students were included in the study. Data was collected using a structured interviewed questionnaire adopted from National centre for injury prevention and control of the centre for disease control and prevention. Results: The total attitude score toward violence was $53.02 \pm 11.74$, (48.0\%) of the studied medical students show moderate attitude toward violence. There was a highly statistically significant relationship between violence attitude level and Smoking status, Taking Anxiolytics, Analgesics and Alcohol. Ordinal logistic regression analysis shows that Students' gender, grade, smoking status and analgesic intake are independent predictors of total attitude score toward violence $(\mathrm{P}<0.05)$. Conclusion: An increase in attitude score towards violence among medical students is well observed. Male gender, older student ages, smoking and analgesics intake are important influencing factors that require special attention while designing intervention programs aiming at reducing violence rates among youth.

Key words: Attitude towards Violence - Health-related habits-Medical students

Corresponding author:_Prof. Aisha Aboul Fotouh. E-mail: aishafotouh@yahoo.com

\section{Introduction:}

Youth violence (involving people between the ages of 10 and 29 years) includes a range of aggressive acts from bullying and physical fighting, to more serious forms of assault and homicide ${ }^{1}$. In fact the interpersonal violence among adolescents has become an increasingly important global public health concern in recent years ${ }^{2}$.
Nearly one third of adolescents from North America and Europe reported being in a physical fight within a year to a year and a half prior to being surveyed ${ }^{3}$.

In 2000, violence among young people left an estimated 199000 youths dead - a rate of 9.2 per 100000 . The highest rates of youth homicide are found in Africa and Latin 
America. In the Middle East and SubSaharan Africa, more than half of adolescents report involvement in physical fighting ${ }^{4}$. Prevalence rates of physical fighting and other forms of interpersonal violence in low- and middle-income countries particularly those experiencing social and political unrest remain elevated and, in some instances, are increasing ${ }^{1}$.

Violence puts a massive burden on national economies. In calculating the costs of violence to a nation's economy, a wide range of factors need to be taken into consideration besides the direct costs of medical care and criminal justice. Indirect costs may include lost productivity as a result of premature death, injury, absenteeism and diminished quality of life ${ }^{5}$.

The different forms of interpersonal violence share many common underlying risk factors. Some are psychological and behavioral characteristics such as poor behavioral control, low self-esteem, and personality and conduct disorders. Others are tied to experiences, such as lack of emotional bonding and support, early exposure to violence in the home (whether experiencing or witnessing family violence), and family or personal histories marked by divorce or separation. Abuse of drugs and alcohol is frequently associated with interpersonal violence, and poverty as well as income disparities and gender inequality stand out as important community and societal factors ${ }^{6}$.

Studies have also shown a consistent relationship at the individual level between alcohol use, drug abuse and aggressive behavior, especially in the presence of social cues that would normally elicit an aggressive response; the consumption of alcohol increases the aggressiveness of this response. In nearly 40 studies of violent offenders, and an equal number of studies of victims of violence, alcohol involvement was found in about $50 \%$ of the events and people examined ${ }^{7}$.

Pervasive exposure to violence can lead youth to disregard the use of non-violent tactics when confronted with a conflict. Attitudes towards the use of aggression as being necessary to resolve conflicts may actually cause youth to attend to more hostile aspects of their social cues in their environment, and as a result, discouraging youth from learning skills that are necessary for peaceful conflict resolution ${ }^{8}$.

The encouragement to use violence, particularly among males, emerges from a complex socialization process that begins at an early age where boys are taught how to be aggressive. Initially, it may start as boys wrestling with each other .The socialization process of young males towards violence continues by the reinforced belief that crying is for girls and that men should hold all emotional reactions inside so as not to portray weakness ${ }^{9}$.

Many studies have been conducted to explore the attitude of university students towards violence in the Middle East. A study was conducted in Jordan to identify the attitudes of Princess Rahma College students have towards University Violence, by exploring different variables that vary from the level of violence (Low, medium or high), to gender, educational achievement and academic year. The study concluded that the tendencies and inclinations of the students towards violence were low. There were statistical differences in the attitudes of the students because of the differences in gender, the differences in the level of educational achievements as well as differences in the academic year ${ }^{10}$.

Egypt has gone into many political changes and two revolutions that affected all the Egyptians socially, financially and emotionally as well. Youth (particularly university students in Cairo) were in the frontlines of all these changes and were 
affected a lot .That's why studying attitude of violence among university students is of a pressing need to be investigated, provoked and managed in the near future.

The aim of the present study is to measure medical students' attitude toward violence at Ain Shams university hospital and to find out relations between medical students' attitude scores toward violence, demographic variables, and health-related habits (smoking, drug abuse).

\section{Methods:}

Descriptive cross-sectional study was carried out at Faculty of Medicine, Ain Shams University located in Abbasssia square in Cairo, on Medical Students and House officers with the following Inclusion criteria: Students from Grade 1 to Grade 6 and House officers who agree to participate will be included in the study. Exclusion criteria: all foreign Students were excluded as they don't represent the Egyptian culture and through they could bias the results (Attitude scores toward violence) and of course those who disagree to participate in the study. Sample size was calculated using OpenEpi, Version 3, open source calculator; taking into consideration that total number of students in addition to the number of house officers in the year 2015-2016 was equal to 6965 . The Sample size was calculated for the preclinical students and clinical students to represent their attitude toward violence as it was revealed from the literature that attitude toward violence increase as students advances in age and educational grades; The recommended sample size was 1116 medical students; given that the sample size calculated at confidence level of $99.0 \%$ and power of $80.0 \%$ and that the prevalence of violence is $50 \% \pm 5$; The researchers increase the sample size to 1257 students to give the researchers the chance to greatly represent medical students in different grades of the faculty of medicine as attitude towards violence among youth is a very sensitive and pressing need to be explored in a meticulous way as it affects the political situation in Egypt nowadays. Data was collected using interview questionnaire which was adopted from a guide produced by National Center for Injury Prevention and Control of the Centers for Disease Control and Prevention named "Measuring Violence-Related Attitudes, Behaviors, and Influences among Youths: A Compendium of Assessment Tools; Second Edition" ${ }^{11}$. Reliability of the questionnaire was measured by Cronbach's alpha coefficient and was found to be 0.859 .

Scoring System: Total Attitude score toward violence was calculated by summing up number of items in the questionnaire. Attitude percent score was calculated by dividing the Total attitude score by (No. of questionnaire items $=23$ multiplied by 3 which is the max item score)*100 .Attitude percent score $=$ Total Attitude score/69*100. Attitude toward violence was classified as High, Moderate and Low tendency for violence as follow: Less than $50.0 \%$ was considered Low, 50.0\%-75.0\% was considered Moderate, More than $75.0 \%$ was considered high

Data Management and Analysis: The collected data was revised, coded, tabulated and introduced to personal computer then finally analyzed using statistical package for social sciences (IBM SPSS Version 20).

Ethical Consideration: Administrative approval from Vice Dean for Student Affairs and Faculty of Medicine, Ain Shams University Ethical committee board approval were obtained to carry out the study. Anonymous questionnaires were used, and confidentiality of the data was assured.

\section{Results}

Out of 1257 participants, (54.4\%) were males and $(45.6 \%)$ were females, the mean 
age of the studied medical students was 21.5 \pm 2.07 ; A stratified random sample included students from preclinical and clinical grades (45.7\% from preclinical grades and $54.3 \%$ from clinical grades). Regarding medical students' fathers and mothers education; the majority $(63.7 \%) \&(61.2 \%)$ respectively were university graduates, while about one quarter $(24.4 \%)$ and $(16.8 \%)$ respectively performed post graduate studies. Concerning Smoking status; about $(11.5 \%)$ of the studied students mentioned that they were smokers (Table 1).

Regarding heath related habits; $(5.3 \%)$ of the medical students used to take Anxiolytics; (3.3\%) mentioned they take analgesic drugs, (3.0\%) drink alcohol, $(0.8 \%)$ take sedative hypnotics; about $(6.1 \%)$ had history of chronic disease. Among those who had chronic diseases; the commonest chronic disease among medical students was bronchial asthma (29.7\%), Irritable bowel disease (17.6\%) followed by Diabetes Mellitus (14.9\%) and hypertension (13.5\%) (Table 2).

The total attitude score toward violence was $53.02 \pm 11.74$; where $(46.7 \%)$ of the studied medical students show mild attitude toward violence, $(48.0 \%)$ of the studied medical students show moderate attitude toward violence; while $(5.3 \%)$ show high attitude toward violence; Moreover; there was a highly statistically significant difference of student attitude level toward violence in preclinical grades as compared to clinical grades $(3.8 \%$ students showed severe levels of violence in preclinical grades compared to $6.6 \%$ in clinical grades) $(\mathrm{P}<0.01)$ (Table 3).

Regarding the relationship between total attitude level toward violence and students' heath related habits; there is a highly statistically significant difference between males and females' attitude level toward violence; where Males show higher attitude level than females toward violence $(7.7 \%$ of males versus $2.4 \%$ of females) show severe attitude level toward violence; In addition to that there was a highly statistically significant relationship between violence attitude level and Smoking status, Taking Anxiolytics, Analgesics and Alcohol, (18.1\% of smokers versus $3.7 \%$ of non smokers), (13.4\% of those who take Anxiolytics versus $4.9 \%$ of those who don't take Anxiolytics), (26.2\% of those who take analgesics versus $4.6 \%$ of those who don't take analgesics) and (15.8\% of those who drink alcohol versus $5.0 \%$ of those who don't drink alcohol) had High attitude toward violence $(\mathrm{P}<0.01)$. On contrast; there is a statistically insignificant relationship between total attitude score toward violence and Father and mother education, use of sedative hypnotics and Presence of chronic disease $(\mathrm{P}>0.05)$ (Table 4). Ordinal Logistic regression analysis shows that Students' gender, grade, smoking status and analgesic intake are independent predictors of total attitude score toward violence $(\mathrm{P}<0.05)$ (Table 5).

\section{Discussion:}

Medical students have special characteristics as compared with students from other universities as medical students who get accepted to medical schools or as we call here in Egypt "Faculty of Medicine" are the top students around the country. The selection process totally depends on the scores of final exams in high school. Since joining the faculty of medicine is highly desired in Egyptian culture. Students in the current study were stratified according to gender and Educational grade to ensure generalization of study findings to the study population. Medical students' fathers and mothers were highly educated; the majority $(63.7 \%) \&(61.2 \%)$ were university graduates, while about one quarter $(24.4 \%)$ and $(16.8 \%)$ respectively performed post graduate studies. Concerning Smoking 
status; about (11.5\%) of the studied students mentioned that they are current smokers; with an average smoking duration of $3.36 \pm$ 2.54. This finding agreed with a study carried out by Khan et al., 2012 ${ }^{12}$; who mentioned that current users of cigarettes comprised $17.4 \%$, and current users of water pipe 'sheesha' comprised $17.6 \%$. The vast majority $(87.7 \%)$ of students believed that smoking is a public health problem in Cairo and supported restriction of tobacco. The overestimated rate of current smokers compared to the current study could be explained by the fact that researchers selected students from the final year only of the faculty of medicine which is expected to include high number of smokers as smoking as a practice increases with Age. The rates of smoking among male physicians were alarmingly high when compared; in Canada (8\%) (Frank \& Segura, 2009) ${ }^{13}$, Switzerland (12.6\%) (Sebo et al., 2007) ${ }^{14}$ and Japan (16.2\%) (Wada et al., 2011) ${ }^{15}$. These observed differences might be affected by the definition of a smoker and distribution of age and gender differences among physicians.

Regarding the relationship between total attitude level toward violence and students' gender ; there is a highly statistically significant difference between attitude level toward violence and students gender; where Males show higher attitude level than females toward violence; This study finding agree with Shapiro et al., 1998 ${ }^{16}$ who performed a survey on 1,164 students; The study concluded that Boys produced higher attitude scores toward violence than did girls.

Two moderate risk factors emerge in childhood, being male and aggression. Boys (and young men) are far more likely than girls to be violent, yet some researchers have suggested that sex is a risk marker rather than a risk factor. A risk marker is a characteristic or condition that is associated with known risk factors but exerts no causal influence of its own (Rockville, 2001) ${ }^{17}$.

The current study found a highly statistically significant relationship between violence attitude level and (smoking, Taking Anxiolytics and Alcohol). These study findings are in concordance with Austin and his colleagues, $2007^{18}$ who reported that students who engage in one form of risktaking behavior generally engage in other types of as well. This finding was based on the analysis of 2003-2005 data from the California Healthy Kids Survey (CHKS) involving over 560,000 students across California which indicated that current smokers are significantly more likely than nonsmokers to engage in alcohol and other drug (AOD) use, be involved in violence and gang membership, and experience school-related problems and disengagement.

Many Studies confirm the connection between genetic factors and personality traits (like un healthy behaviors) which can create a base for investigations designed to identify which genes are associated with a complex network of unhealthy behaviors, such as aggression, excessive alcohol consumption, and smoking, as well as with mental disorders such as schizophrenia, in order to improve treatment programs (Kahn et al., 2003) ${ }^{19}$.

Regarding the relation between analgesic abuse and attitude toward violence; the current study reveals that there is a highly statistically significant relationship between violence attitude level and analgesic abuse (e.g. NSAIDs and Tramadol).

Generally; Physicians confront the dilemma of balancing pain relief when prescribing analgesics against the reality that some patients may misuse and divert these medications. Physicians must be able to safely and effectively prescribe scheduled drugs and, at the same time, must identify and manage misuse and abuse in their practices. Ethics drive physicians to 
prescribe, but fear of sanctions may affect physician prescribing behaviors, which might compromise quality of care. The problem cannot be ignored because abusers often face complications, such as: Overdoses, Addiction and dependence, Adverse effects, Social and family dysfunction and Criminal consequences (Green et al., 2009; Blazer \& Wu, 2009) $)^{20,21}$.

The current study found that there was a highly statistically significant difference of student attitude level toward violence in preclinical grades as compared to clinical grades $(\mathrm{P}<0.05)$. This finding agree with Shapiro et al., $1998^{16}$ who found that student Scores and attitude toward violence increases as students grade advances.

\section{Conclusions and recommendations:}

The study concluded that medical students' attitude towards violence level increase with the increase in the students' age and educational grade. There is very intimate relationship between high violence attitudes and risky behaviors among them as smoking, drinking alcohol and analgesic drug abuse and thus we recommend the following: 1) Enhance the awareness of the staff towards the violent attitude of the students and measures to combat this phenomenon.2) Health education program targeting drug abuse and smoking cessation must be held yearly to the newly admitted students, as well as the freshly graduates with the availability of professional aid to addicts who need further assistance.3) Special recreation and aggression relieve activities should take their share in the faculty schedule and be accessible to all undergraduates.

\section{References:}

1. Krug EG, Dahlberg LL, Mercy JA, Zwi AB, Lozano R. (2002). World report on violence and health.Geneva: World Health Organization.
2. Sugimoto-Matsuda JJ, Braun KL. (2013). The role of collaboration in facilitating policy change in youth violence prevention: a review of the literature. Prevention Science

3. Eaton DK, Kann L, Kinchen S, Shanklin S, Flint KH, Hawkins J, HarrisWA, Lowry R,McManus T, Chyen D, Whittle L, Lim C,Wechsler H, Centers for Disease Control and Prevention (CDC). (2012). Youth Risk Behavior Surveillance-United States 2011. Morbidity and Mortality Weekly Report. Surveillance Summaries 61(4):1-162.

4. Gofin R, Palti H, Mandel M. (2000). Fighting among Jerusalem adolescents: personal and school related factors. Journal of Adolescent Health 27:218-223.

5. Tercero F (1999). On the epidemiology of injury in developing countries: a one-year emergency room-based surveillance experience from Leo 'n, Nicaragua. International Journal for Consumer and Product Safety, 1999, 6:33-42).

6. Bross DC (2000). World perspectives on child abuse: the fourth international resource book. Denver, CO, Kempe Children's Center, University of Colorado School of Medicine.

7. Parker RN and Auerhahn K (1998). Alcohol, Drugs and Violence Annu. Rev. Sociol. 1998. 24:291-311

8. Vernberg, E. M., Jacobs, A. K., \& Hershberger, S. L. (1999). Peer victimization and attitudes about violence during early adolescence. Journal of Clinical Child Psychology, 28(3), 386-395

9. Scher, M., \& Stevens, M. (1987). Men and violence. Journal of Counseling and Development, 65, 351-354.

10. Ghoneem A.K (2012). Attitudes of Princess Rahma College Students toward University Violence International Education Studies Vol. 5, No. 3; June 2012.

11. Centre of Disease Prevention and Control (CDC) (2015). Measuring ViolenceRelated Attitudes, Behaviors, and Influences 
among Youths: A Compendium of Assessment Tools, Second Edition

12. Khan AA1, Dey S, Taha AH, Huq FS, Moussawi AH, Omar OS, Soliman AS (2012). Attitudes of Cairo University medical students toward smoking: the need for tobacco control programs in medical education; J Egypt Public Health Assoc.; 87(1-2):1-7.

13. Frank E, Segura C: Health practices of Canadian physicians. Can Fam Physician 2009, 55:810-811.

14. Sebo P, Bouvier Gallacchi M, Goehring

C, Künzi B, Bovier PA (2007): Use of tobacco and alcohol by Swiss primary care physicians: a cross-sectional survey. BMC Public Health 2007, 7:5.

15. Wada K, Yoshikawa T, Goto T, Hirai A, Matasushima E, Nakashima Y, Akaho R, Kido M, Hosaka T (2011): Lifestyle habits among physicians working at hospitals in Japan. Japan Med Assoc J, 54(5):318-324.

16. Shapiro JP, Dorman RL, Welker CJ, Clough JB (1998). Youth attitudes toward guns and violence: relations with sex, age, ethnic group, and firearm exposure; J Clin Child Psychol.; 27(1):98108.
17. Rockville (2001). Youth Violence: A Report of the Surgeon General. Office of the Surgeon General (US); National Center for Injury Prevention and Control (US); National Institute of Mental Health (US); Center for Mental Health Services (US). 18. Austin, G., McCarthy, W., Slade, S., and Bailey, w. (2007) Links between Smoking and Substance Use, Violence, and School Problems. CHKS Factsheet \#5. Los Alamitos, CA: West Ed.

19. Kahn RS, Khoury J, Nichols WC, Lanphear BP (2003). Role of dopamine transporter genotype and maternal prenatal smoking in childhood hyperactiveimpulsive, inattentive, and oppositional behaviors. J Pediatr; 143(1):104-10.

20. Green TC, Grimes Serrano JM, Licari A (2009). Women who abuse prescription opioids: findings from the Addiction Severity Index-Multimedia Version Connect prescription opioid database. Drug Alcohol Depend.; 103(1-2):65-73.

21. Blazer DG \& Wu LT (2009). Nonprescription use of pain relievers among middle aged and elderly community adults: National Survey on Drug Use and Health. J Am Geriatr Soc.; 57:1252-1257. 
Table (1): Characteristics of the studied Students

\begin{tabular}{|c|c|c|c|}
\hline $\begin{array}{l}\text { Characteristics } \\
\text { Students }\end{array}$ & of the studied & Mean & SD \\
\hline \multirow{2}{*}{\multicolumn{2}{|c|}{ Age }} & 21.5 & 2.07 \\
\hline & & No. & $\%$ \\
\hline \multirow{2}{*}{ Gender } & Male & 684 & $54.4 \%$ \\
\hline & Female & 573 & $45.6 \%$ \\
\hline \multirow{2}{*}{ Grade } & Preclinical & 575 & $45.7 \%$ \\
\hline & Clinical & 682 & $54.3 \%$ \\
\hline \multirow{6}{*}{$\begin{array}{l}\text { Father } \\
\text { Education }\end{array}$} & Illiterate & 14 & $1.1 \%$ \\
\hline & Read and Write & 23 & $1.8 \%$ \\
\hline & Preparatory & 32 & $2.5 \%$ \\
\hline & Secondary school & 80 & $6.4 \%$ \\
\hline & $\begin{array}{l}\text { University } \\
\text { Graduate }\end{array}$ & 801 & $63.7 \%$ \\
\hline & $\begin{array}{ll}\text { Post } & \text { graduate } \\
\text { studies } & \end{array}$ & 307 & $24.4 \%$ \\
\hline \multirow{6}{*}{$\begin{array}{l}\text { Mother } \\
\text { Education }\end{array}$} & Illiterate & 33 & $2.6 \%$ \\
\hline & Read and Write & 42 & $3.3 \%$ \\
\hline & Preparatory & 43 & $3.4 \%$ \\
\hline & Secondary school & 159 & $12.6 \%$ \\
\hline & $\begin{array}{l}\text { University } \\
\text { Graduate }\end{array}$ & 769 & $61.2 \%$ \\
\hline & \begin{tabular}{|ll}
$\begin{array}{l}\text { Post } \\
\text { studies }\end{array}$ & graduate \\
\end{tabular} & 211 & $16.8 \%$ \\
\hline \multirow{2}{*}{ Smoking status } & No & 1113 & $88.5 \%$ \\
\hline & Yes & 144 & $11.5 \%$ \\
\hline
\end{tabular}


Table (2): Drug intake and Presence of chronic disease in the studied students

\begin{tabular}{|c|c|c|c|}
\hline \multicolumn{2}{|c|}{$\begin{array}{l}\text { Drug intake and Presence of chronic } \\
\text { disease in the studied students }\end{array}$} & \multirow{2}{*}{$\begin{array}{l}\text { No. } \\
1190\end{array}$} & \multirow{2}{*}{$\%$} \\
\hline & No & & \\
\hline Anxiolytics & Yes & 67 & $5.3 \%$ \\
\hline \multirow{2}{*}{ Analgesics } & No & 1215 & $96.7 \%$ \\
\hline & Yes & 42 & $3.3 \%$ \\
\hline \multirow{2}{*}{ Alcohol } & No & 1219 & $97.0 \%$ \\
\hline & Yes & 38 & $3.0 \%$ \\
\hline \multirow{2}{*}{ Sedative Hypnotics } & No & 1247 & $99.2 \%$ \\
\hline & Yes & 10 & $0.8 \%$ \\
\hline \multirow{2}{*}{$\begin{array}{l}\text { Presence of Chronic } \\
\text { ds }\end{array}$} & No & 1180 & $93.9 \%$ \\
\hline & Yes & 77 & $6.1 \%$ \\
\hline \multirow{14}{*}{ Type of chronic ds $(*)$} & Diabetes Mellitus & 11 & $14.9 \%$ \\
\hline & Bronchial Asthma & 22 & $29.7 \%$ \\
\hline & Hypertension & 10 & $13.5 \%$ \\
\hline & $\begin{array}{ll}\text { Irritable } & \text { Bowel } \\
\text { Disease } & \\
\end{array}$ & 13 & $17.6 \%$ \\
\hline & \begin{tabular}{ll|} 
Mitral & Valve \\
Prolapse & \\
\end{tabular} & 2 & $2.7 \%$ \\
\hline & Disc Prolapse & 1 & $1.4 \%$ \\
\hline & Migraine & 2 & $2.7 \%$ \\
\hline & Gastritis & 3 & $4.1 \%$ \\
\hline & Neuropathic Pain & 1 & $1.4 \%$ \\
\hline & $\mathrm{HCV}$ & 1 & $1.4 \%$ \\
\hline & Hyperlipidemia & 1 & $1.4 \%$ \\
\hline & Allergic Rhinitis & 5 & $6.8 \%$ \\
\hline & PCO & 1 & $1.4 \%$ \\
\hline & Epilepsy & 1 & $1.4 \%$ \\
\hline
\end{tabular}

(*) Percentages are presented as a proportion from those who have chronic disease) 
Table (3): Medical Students' Attitude Levels toward Violence

\begin{tabular}{|c|c|c|c|c|c|c|c|c|}
\hline \multirow{2}{*}{$\begin{array}{lr}\text { Medical } & \text { Students' } \\
\text { Attitude } & \text { Levels } \\
\text { Toward Violence }\end{array}$} & \multicolumn{2}{|c|}{ Mild } & \multicolumn{2}{|c|}{ Moderate } & \multicolumn{2}{|c|}{ Severe } & \multirow{2}{*}{$\begin{array}{c}\text { Chi } \\
\text { square }\end{array}$} & \multirow[b]{2}{*}{ P-value } \\
\hline & No. & $\%$ & No. & $\%$ & No. & $\%$ & & \\
\hline Preclinical grades & 297 & 51.7 & 256 & 44.5 & 22 & 3.8 & \multirow{2}{*}{12.696} & \multirow{2}{*}{$0.002^{* *}$} \\
\hline Clinical grades & 290 & 42.5 & 347 & 50.9 & 45 & 6.6 & & \\
\hline \multirow{3}{*}{ Total Attitude score } & 587 & 46.7 & 603 & 48.0 & 67 & 5.3 & & \\
\hline & Min & Max & \multicolumn{2}{|c|}{ Mean } & \multicolumn{2}{|c|}{ SD } & & \\
\hline & 33.33 & 98.55 & \multicolumn{2}{|c|}{53.0213} & \multicolumn{2}{|c|}{11.74291} & & \\
\hline
\end{tabular}

(**) Highly statistically significant at $P<0.01$ 
Aisha M Aboul Fotouh, et al Violence attitude and its relation to Health-related habits in medical 80

Table (4): Relationship between Total Attitude Score toward violence and Medical Students characteristics

\begin{tabular}{|c|c|c|c|c|c|c|c|c|c|}
\hline \multirow{2}{*}{\multicolumn{2}{|c|}{ Medical Student Characteristics }} & \multirow{2}{*}{\multicolumn{2}{|c|}{$\begin{array}{c}\text { Mild } \\
(<\mathbf{5 0 \%})\end{array}$}} & \multirow{2}{*}{\multicolumn{2}{|c|}{$\begin{array}{c}\text { Moderate } \\
(50 \%-75 \%)\end{array}$}} & \multicolumn{2}{|c|}{$\begin{array}{c}\text { Severe } \\
(>75.0 \%)\end{array}$} & \multirow{2}{*}{$\begin{array}{c}\text { Chi } \\
\text { square }\end{array}$} & \multirow[t]{2}{*}{ P-value } \\
\hline & & & & & & & & & \\
\hline \multirow{3}{*}{ Gender } & & & & & & & & & \\
\hline & Male & 235 & $34.4 \%$ & 396 & $57.9 \%$ & 53 & $7.7 \%$ & \multirow{2}{*}{96.209} & \multirow{2}{*}{$0.000 * *$} \\
\hline & Female & 352 & $61.4 \%$ & 207 & $36.1 \%$ & 14 & $2.4 \%$ & & \\
\hline \multirow{6}{*}{$\begin{array}{l}\text { Father } \\
\text { Education }\end{array}$} & Illiterate & 8 & $57.1 \%$ & 6 & $42.9 \%$ & 0 & $0.0 \%$ & \multirow{6}{*}{ FE\# } & \multirow{6}{*}{0.190} \\
\hline & Read and Write & 10 & $43.5 \%$ & 11 & $47.8 \%$ & 2 & $8.7 \%$ & & \\
\hline & Preparatory & 18 & $56.2 \%$ & 10 & $31.2 \%$ & 4 & $12.5 \%$ & & \\
\hline & Secondary school & 47 & $58.8 \%$ & 31 & $38.8 \%$ & 2 & $2.5 \%$ & & \\
\hline & $\begin{array}{l}\text { University } \\
\text { Graduate }\end{array}$ & 361 & $45.1 \%$ & 399 & $49.8 \%$ & 41 & $5.1 \%$ & & \\
\hline & \begin{tabular}{ll|}
$\begin{array}{l}\text { Post } \\
\text { studies }\end{array}$ & graduate \\
\end{tabular} & 143 & $46.6 \%$ & 146 & $47.6 \%$ & 18 & $5.9 \%$ & & \\
\hline \multirow{6}{*}{$\begin{array}{l}\text { Mother } \\
\text { Education }\end{array}$} & Illiterate & 21 & $63.6 \%$ & 11 & $33.3 \%$ & 1 & $3.0 \%$ & \multirow{6}{*}{ FE\# } & \multirow{6}{*}{0.320} \\
\hline & Read and Write & 17 & $40.5 \%$ & 19 & $45.2 \%$ & 6 & $14.3 \%$ & & \\
\hline & Preparatory & 18 & $41.9 \%$ & 22 & $51.2 \%$ & 3 & $7.0 \%$ & & \\
\hline & Secondary school & 75 & $47.2 \%$ & 77 & $48.4 \%$ & 7 & $4.4 \%$ & & \\
\hline & $\begin{array}{l}\text { University } \\
\text { Graduate }\end{array}$ & 358 & $46.6 \%$ & 372 & $48.4 \%$ & 39 & $5.1 \%$ & & \\
\hline & $\begin{array}{ll}\text { Post } & \text { graduate } \\
\text { studies } & \\
\end{array}$ & 98 & $46.4 \%$ & 102 & $48.3 \%$ & 11 & $5.2 \%$ & & \\
\hline \multirow{2}{*}{$\begin{array}{l}\text { Smoking } \\
\text { status }\end{array}$} & No & 554 & $49.8 \%$ & 518 & $46.5 \%$ & 41 & $3.7 \%$ & \multirow{2}{*}{73.250} & \multirow{2}{*}{$0.000 * *$} \\
\hline & Yes & 33 & $22.9 \%$ & 85 & $59.0 \%$ & 26 & $18.1 \%$ & & \\
\hline \multirow{2}{*}{$\begin{array}{l}\text { Anxiolytic } \\
\text { S }\end{array}$} & No & 564 & $47.4 \%$ & 568 & $47.7 \%$ & 58 & $4.9 \%$ & \multirow{2}{*}{11.305} & \multirow{2}{*}{$0.004 * *$} \\
\hline & Yes & 23 & $34.3 \%$ & 35 & $52.2 \%$ & 9 & $13.4 \%$ & & \\
\hline \multirow{2}{*}{ Analgesics } & No & 573 & $47.2 \%$ & 586 & $48.2 \%$ & 56 & $4.6 \%$ & \multirow{2}{*}{37.645} & \multirow{2}{*}{$0.000 * *$} \\
\hline & Yes & 14 & $33.3 \%$ & 17 & $40.5 \%$ & 11 & $26.2 \%$ & & \\
\hline \multirow{2}{*}{ Alcohol } & No & 575 & $47.2 \%$ & 583 & $47.8 \%$ & 61 & $5.0 \%$ & \multirow{2}{*}{10.138} & \multirow{2}{*}{$0.006 * *$} \\
\hline & Yes & 12 & $31.6 \%$ & 20 & $52.6 \%$ & 6 & $15.8 \%$ & & \\
\hline \multirow{2}{*}{$\begin{array}{l}\text { Drug } \\
\text { addiction }\end{array}$} & No & 584 & $46.8 \%$ & 597 & $47.9 \%$ & 66 & $5.3 \%$ & \multirow{2}{*}{ FE\# } & \multirow{2}{*}{0.324} \\
\hline & Yes & 3 & $30.0 \%$ & 6 & $60.0 \%$ & 1 & $10.0 \%$ & & \\
\hline Presence & No & 552 & $46.8 \%$ & 563 & $47.7 \%$ & 65 & $5.5 \%$ & & \\
\hline $\begin{array}{l}\text { of Chronic } \\
\text { ds }\end{array}$ & Yes & 35 & $45.5 \%$ & 40 & $51.9 \%$ & 2 & $2.6 \%$ & 0.1447 & 0.500 \\
\hline
\end{tabular}

(\#) Fisher exact test was used as (20.0\%) of the cells or more have expected count less than 5

(**) Highly significant at $P<0.01$

N.B. Percentages are taken from Rows 
Table (5): Ordinal Logistic Regression displaying independent predictors of Medical Students' Attitude Score toward violence

\begin{tabular}{|l|r|r|r|r|r|}
\hline & \multirow{2}{*}{ Estimate } & \multirow{2}{*}{ Wald } & \multicolumn{2}{l|}{ Sig. } & \multicolumn{2}{|l|}{ 95\% Confidence Interval } \\
\cline { 6 - 7 } & & & & Lower Bound & Upper Bound \\
\hline Grade & -.341 & 8.639 & $.003^{* *}$ & -.569 & -.114 \\
\hline Gender & .999 & 70.234 & $.000^{* *}$ & .765 & 1.233 \\
\hline Smoking status & -.928 & 22.732 & $.000^{* *}$ & -1.310 & -.547 \\
\hline Anxiolytics & -.249 & .875 & .350 & -.770 & .273 \\
\hline Analgesics & -1.005 & 9.007 & $.003^{* *}$ & -1.661 & -.349 \\
\hline Alcohol & -.423 & 1.554 & .213 & -1.089 & .242 \\
\hline
\end{tabular}

(**) Highly significant at $P<0.01$ 